\title{
ONTOLOGIALLA ON OIKEUS VAIN KYSYMYKSEEN DERRIDAN HISTORIALLINEN JÄLKIKYSYMYS
}

EDMUND HUSSERL: Geometrian alkuperä. Johdanto Jacques Derrida. Suomennos Kaisa Heinlahti ja Tuukka Perhoniemi. NiinENäin 2008.

\section{JÄLKIKÄTINEN KYSYMYS \\ ALKUPERÄSTÄ \\ FENOMENOLOGIAN JA MARXISMIN VÄLISSÄ}

Eräänä Jacques Derridan radikaaleimpana avauksena voitaisiin totutusta poiketen pitää hänen tapaansa asettaa kysymys historiallisuudesta. Tavallisimmin Derridan ajattelu on nimittäin tullut jäsennetyksi erilaisten dekonstruktio-termin ympärille ryhmittyvien käsitteiden kautta. Tällöin se on ollut helppo käsittää jonkinlaisena kirjallisuuden- ja kulttuurintutkimuksen piiriin kuuluvana, "ranskalaiseksi" kutsutun ajattelun arroganttina ääritapauksena.

Derridan kysymyksenasettelua ja tyyliä voi mahdollisesti pitää omaperäisenä ja ongelmallisenakin, mutta Derridan varhaisissa Husserlin ajattelua koskevissa tutkimuksissa suhde filosofian perinteiseen kysymyksenasetteluun on ilmeinen ja kirkas. Vuonna 1954 pidetty esitelmä "Genèse et structure" et la phénomenologie, samana vuonna valmistunut tutkielma Le problème de la genèse dans la philosophie de Husserl, vuonna 1967 julkaistu La voix et le phénomène sekä nyt suomennettu johdanto Husserlin Geometrian alkuperä-tutkielman ranskannokseen L'origine de la géométrie (1962) ovat tässä mielessä hyvin selkeitä. Ne ovat jo muodoltaankin hyvin pitkälle ranskalaisen akateemisen perinteen mukaisia lähiluentoja, tekstikommentaareja - joskin tietysti Derridan erityinen käsitys siitä, mitä luenta ja lukeminen ovat, on jo toisaalta helposti nähtävissä.

Kyseisten tekstien perinteisyyttä ja lähestyttävyyttä lisää vielä se, että niiden suhde Husserliin on hyvin läheinen ja tiukka. Husserlilta periytyvä ajattelun ankaruus on selkeästi esillä. Geometrian alkuperän johdannossa kysymyksenasettelu onkin tässä mielessä yksinkertainen. Kun tietty Derridan myöhemmän tuotannon lukemisen työläys muodostuu ajattelun liikkeen, käsitteellisten siirtymien ja tekstin motivaatioiden jäljittämisestä, Geometrian alkuperän johdanto on suhteellisen suoraviivainen.

Tietyissä kohdin Johdanto-teksti jopa sallii sellaisen erityisen kokemuksen, jossa ajattelun ankaruus alkaa lakonisuudessaan ja osuvuudessaan lähestyä koomista. Tällöin ajattelun kaikkein terävimmät liikkeet ovat onnistuessaan, kuten niin usein ja äärimmillään Hegelillä, yksinkertaisesti naurattavia. Tämän voi Johdannossa kokea, kun Derrida seuraa Husserlin kysymystä geometrian alkuperästä pisteeseen, jossa ajatellaan hypoteettista ensimmäistä geometrikkoa empiiristen kolmioidensa kanssa. Kysymykset merkityksellisyyden pysyvyydestä ja ideaalisuuden luonteesta ylipäätään kääntyvät perusluonteisuudessaan huvittaviksi kysymyksiksi: Miten yksittäisen tietoisuuden oivallus havaitun kolmion ideaalisuudesta koskee todella ideaalista objektia? Miten ensimmäisen kerran syntynyt ideaalisuus kestää "ensimmäisen keksijäsielun" tietoisuudessa? Ja entä kun tämä kummallinen proto-geometrikko keskeyttää kontemploivan työnsä tai nukahtaa miten hän ikinä enää voi "uudelleenaktivoida" tuon järisyttävän oivalluksensa!

Nyt suomennettu teos koostuu siis kahdesta tekstistä ja säilyttää siten Ranskassa vuonna 1962 ilmestyneen Husserl-käännöksen rakenteen. Kyse on Husserlin lyhyehköstä tutkielmasta vuodelta 1939 nimeltään Die Frage nach dem Ursprung der Geometrie als intentional-historisches Problem, jonka Derrida tuolloin käänsi ranskaksi ja Derridan itsensä kirjoittamasta pitkästä johdannosta. Teos on keskeinen osa ranskalaista Husserl-vastaanottoa, mutta kyse ei ole "vain" fenomenologiasta, vaan osasta tiettyä asetelmaa tuon ajan keskustelussa. Kun tiedetään, että viime vuosisadan puolenvälin ranskalaista akateemista elämää määrittää kaksi tekijää, yhtäältä fenomenologia ja toisaalta marxismi (joiden väliin tuon ajan ajattelijasukupolvi paikantuu, kuten Michel Foucault on sanonut), niin myös tämä teos on mielekästä asettaa kyseiseen asetelmaan, siis fenomenologian ja ranskalaisen althusserilaisen marxismin väliin. Tilanteen voi tunnetusti ymmärtää myös fenomenologian ja strukturalismin väliseksi kiistaksi.

Positioita-teoksen haastattelussa Derrida itse selventääkin omaa varhaista suhdettaan Husserlin fenomenologiaan sanomalla, että juuri tarve löytää keinoja vallalla olleen strukturalistisen diskurssin avaamiseksi motivoi lukemaan Husserlia. Fenomenologian ja marxismin, tai fenomenologian ja strukturalismin, välistä kiistaa voi avata moniin eri suuntiin, mutta eräs tästä välistä kumpuava tärkeä kysymys on kysymys historiallisuudesta. Mitä on merkityksellisen maailman py- 
syvyyden, ideaalisuuden historiallisuus?

Derridan tarkoituksena on Husserlia seuraten löytää sellainen historiallisuuden käsite, joka ei olisi yliajallisten ideaalisten olemusten pysyvyyttä eikä historisismia, siis historiattomuutta kahdessa mielessä. Tällöin kysymys on toisin sanoen ideaalisuuden historiallisuudesta, siitä kuinka ideaalisten olioiden historiallisuutta olisi ajateltava. Ja siksi kyse on nimenomaan geometriasta.

Derrida seuraa Husserlia siinä, että geometria on ideaalisuutta ylipäätään koskeva tiede. Geometriaa ei tässä siis tarkastella ikään kuin aatetai oppihistoriallisesti vaan kysymyksenä ideaalisuudesta. Mitä on ideaalisuus sen kaikkein yleisimmässä mielessä?

Kysymys geometrian alkuperästä on siten kysymys ideaalisuudesta yleensä. Derrida on kiinnostunut Hussserlin tavasta asettaa kysymys geometrisen olion ideaalisuudesta siksi, että Husserl ajattelee ideaalisuutta radikaalilla tavalla ajallisena. Geometrian ideaalinen objekti ei yhtäältä ole yliajallinen, mutta toisaalta se ei myöskään ole ajallisesti satunnainen, empiirinen tosiasia. Husserlin kysymyksenasettelun erityisyys seuraa siitä, että hän asettaa geometrian alkuperän. Tämä ei kuitenkaan tarkoita sitä, että tällöin etsittäisiin todella joskus elänyttä ja välttämättä fiktiiviseksi jäävää proto-tiedemiestä, "Thalesta", vaan alkuperän asettamista kysymyksenä alkuperästä, alkuperään suuntautuvaa jälkikysymystä, Rückfragea. Tämä on Derridan historiallisuuden ajattelun lähtökohta.

\section{IDEAALISEN HISTORIALLINEN KERROSTUMINEN}

Husserlia vaivaa tunnetusti kysymys tieteen perustasta. Tällöin hän ei yhtäältä tyydy positivistiseen käsitykseen siitä, että kaikki ideaalinen olisi ikään kuin jäännöksettä tieteen käsillä. Toisaalta myöskään historisismi ei ole Husserlille vaihtoehto. Tämän sijaan Husserl lähtee kysymään historian luonnetta - yhtä aikaa historiallisuuden olemusta ja olemusten historiallisuutta. Derridan mukaan Husserlin kysymyksenasettelussa onkin erityistä se, että tämä ymmärtää ideaalisuuden kysymyksen koskevan alkuperää. Ideaalisuuden olemusta on kysyttävä ideaalisen alkuperänä.

Miten ideaalisuus siis syntyy - tai kuten Husserl kysyy: "Miten geometrian ideaalisuus kehittyy ideaaliseksi objektiivisuudeksi ensimmäisestä yksilön sisäisestä alkuperästä, jossa se on muodoste ensimmäisen keksijäsielun tietoisuustilassa?" (Geometrian alkuperä, s. 196). Keskeistä on kysymys liikkeestä, ideaalisen kehittymisestä, sen genesiksestä. Geometriaa tarkastellaan tällöin tieteenä, jossa kyse on nimenomaan ideaalisuuden syntymisestä.

Husserl väittää, että ideaalisuuden lähtökohtana on oltava havaintokokemus. Tämä ei kuitenkaan merkitse positivismia tai empirismiä, sillä vaikka lähtökohtana onkin havaintokokemuksen annettuus, kyse on silti välttämättä annettuuden tuonpuoleisesta, sen transsendenssista. Ideaalisen alkuperässä on kokemus, mutta tämä kokemus ei koskaan ole palautettavissa. Sen ideaalisuus avautuu vain jälkikätisesti kysymyksen kaut- ta. Mikä siis on ideaalisuuden syntymisen tapahtuma? Mikä saa kokemuksen yksittäisyyden kehittymään ideaalisuuden yleisyydeksi?

Husserl johtaa kysymyksen päättäväisesti kieleen ja erityisesti kirjoitukseen. Yksittäinen kokemus saa ideaalisuutensa kirjoitetussa muodossa. Kirjoitettu kieli mahdollistaa "kommunikoinnin ilman välitöntä tai välillistä henkilökohtaista puhetta", kuten Husserl kirjoittaa (GA, 201). Hypoteettinen yksittäisen keksijäsielun hallussa oleva ideaalisuus ruumiillistuu yleiseksi, varsinaiseksi ideaalisuudeksi kieleen tullessaan.

Tästä avautuu jo Husserlin omassa tekstissä, mutta erityisesti Derridan Husserl-luennassa hyvin keskeinen rakenne. Objektivoiva idealisaatio tapahtuu kokemuksellisesta annettuudesta lähtien. Tämä tapahtuma on kielen tapahtuma, jossa samalla kun kokemuksen yksittäisyydestä päästään yleisyyteen, menetetään välittömästi tuon lähtökohtana olevan annettuuden välittömyys. Kieli siis mahdollistaa jaettavan merkityksellisyyden, mutta tuottaa samalla tätä merkityksellisyyttä uhkaavan passiivisuuden. Annettuuden aktiivisuus menetetään välttämättä ideaalisuuden ja jaettavuuden vaateessa. Kyse on ilmeisyyden varmuudesta, sen aktiivisuudesta, tämän unohtamisesta ja passiivisuudesta sekä uudelleen aktivoinnin mahdollisuudesta. Husserlin kysymys koskeekin tätä uudelleen aktivointia. Kuinka olisi mahdollista palauttaa ideaalisuuden alkuperässä oleva ilmeisyys?

Oleellista on, että Husserl ei kuvittele yksinkertaisesti paljastavansa tätä "alkuilmeisyyttä" vaan ajattelee ideaalisuutta nimenomaan edellä muotoil- 
tuna paradoksina. Siten vaikka Husserl asettaakin kysymyksen alkuperästä, tätä alkuperäistä ilmeisyyttä ei ole tarkoitus paljastaa.

Ideaalisuus ei paljasta alkuperäänsä. Sen sijaan ideaalisuutta määrittää kerrostuneisuus. Ideaalinen määrittyy perinteessä kerrostumalla. Ideaalisella on kyllä olemus alkuperässään, mutta koska ideaalisuus syntyy vasta tämän alkuperän selventämisessä, sen kieleen tulemisessa, jokainen selventävä askel kohti olemusta on samalla etääntymistä alkuperäisestä ilmeisyydestä. Selventävä $\log O s$ kietoutuu peruuttamattomasti kiinni selventämisen päämäärään, telokseen. Tätä kautta tieteen "edistyminen" ei ole missään mielessä jonkinlaista kumulatiivista tai tarkentuvaa parantumista, vaan juuri logoksen ja teloksen välistä liikettä. "Kaikki edistyminen, jokainen uusimerkityksinen lause (Satz) on samalla loikka (Satz) eteenpäin ja merkityksen kerrostunut (Satzartig) paluu", kuten Derrida Husserlia mukaillen kirjoittaa (GA, 111).

Derridan luennan mukaan Husserlin historiallisuuden ajattelun keskeinen erottelu tapahtuukin tämän ideaalisuuden kerrostumisen liikkeen ja tosiasiallisuuden välillä. Näistä edellinen muodostaa "historiallisuuden a priorin" ja jälkimmäinen "tosiasiahistorian". Historiallinen a priori edeltää tosiasiallisuutta, mutta tämä $a$ priori ei suinkaan ole mikään läsnäolevaksi palautettavissa oleva alkuperäisyys vaan Derridan sanoin "tämän totalisaation ja perinteellistymisen palautumaton sekä puhdas paikka ja liike" (GA, 127), tai kuten Husserl itse kirjoittaa, "alkuperäisestä merkitysten muodostumisesta juontuvaa yhteen- kietoutumisen ja kerrostumisen elävää liikettä" (GA, 215).

Ideaalisuus on siis mahdollista alkuperästään, totaalisesti haltuunotetusta annettuudesta käsin. Tämän alkuperän totaalinen haltuunotto on kuitenkin Husserlille puhtaasti teleologinen horisontti. Ihmisen uudelleenaktivoinnin kyky on rajallinen, välitön kokonaisuus on siltä aina evätty, mutta tämä mahdottomuus ei ole yksinkertaista vajavaisuutta tai jonkinlaista tietokyvyn puutteellisuutta. Kyse on konstitutiivisesta mahdottomuudesta, jonka suhteen määrittyvät sekä ideaalisuus että tätä vastaava käsitys subjektista.

Kun ideaalisuus määrittyy äärettömyytenä, näin käsitettyä subjektia määrittää äärettömään suhteutuminen, äärettömäksi tekemisen kyky ja taipumus - Husserlin sanoin "idealisointi, nimittäin rajojen hylkääminen ja kykyjemme kasvaminen äärettömiksi" (GA, 207). Derridan mukaan tällainen äärettömäksi tekeminen (infinitation) on mukana kaikissa Husserlin ajattelun kriittisissä kohdissa. Husserlin ajattelu nojaa tämän liikkeen mahdollisuuteen, mutta jättää tämän liikkeen luonteen hämäräksi. Idealisoivan aktin selvittämistä lykätään loputtomasti Husserlin tuotannossa.

Idealisoivan aktin selvittäminen lykkääntyy, koska tässä aktissa on kyse selventämisen mahdollisuudesta itsestään. Tämä lykkääntyminen on Husserlin ajattelun voima, tietyn Husserlin ajattelun ytimessä vaikuttavan voiman todellisuutta. Se, että äärettömäksi tekemisen ytimeen ei ole pääsyä, on täsmälleen sellaisen välityksen ja välillisyyden toimintaa, jonka Husserl käsittää historian a prioriksi.

\section{FENOMENOLOGIAN IDEA JA IDEOLOGIA}

Geometrian alkuperässä Husserl etsii siis ideaalista perinteen yhteenkietoutumisen ja kerrostumisen liikkeenä. Puhdas ideaalisuus äärettömän määritettävyyden teloksena on siten Husserlille "intentionaalisen historiallisuuden absoluutti", kuten Derrida kirjoittaa (GA, 172).

Tässä kohtaa Derrida kuitenkin jäljittää Husserlin ajattelusta merkitsevän huojunnan. Kyse on siitä, kuinka ajatella ideaalisuutta ja alkuperää määrittävää äärettömyyttä. Husserl nimittäin puhuu Derridan mukaan kahdesta suhteesta tähän äärettömyyteen. Yhtäältä on kyse äärettömyyden paljastumisesta alkuperäisenä, ideaalisuuden avautumisesta ensimmäistä kertaa. Vaikka Husserl Geometrian alkuperässä nimenomaan asettaa tämän alkuperän saavuttamattomana, tämä saavuttamattomuus tulee ajatelluksi teleologisena horisonttina. Kun kyse on avautumisesta, jonka uudelleenaktivointi on mahdotonta, se on ikuisesti menetetty niin, että se on aina jo haltuunotettu.

Toinen paljastuminen koskee kuitenkin juuri tämän ensimmäisen avautumisen näyttämistä sulkeumana. Tällöin idealisoiva akti ei Derridan mukaan olisikaan liike kohti ensimmäisen vetäytyvän annettuuden palauttamista vaan tämän alkuperäisen avautumisen poispyyhkiytymistä ( $o b$ literation) yhä uudelleen. (GA, 157.)

Derridan mukaan Husserl ajattelee ideaalisuutta suhteessa perinteen alkuun, hengen heräämiseen, mutta_kun hän löytää kirjoituksen välttämättömyyden tässä heräämisessä, hän löytää jotakin, minkä 
seuraukset karkaavat ajattelun otteesta. Husserlin ajattelua vaivaa taipumus sulkea avaamansa ulottuvuus. Kuten Husserl oivaltaakin, ideaalisuuden ehtona on välittömän menettäminen, ensimmäisen avautumisen näyttäminen sulkeumana. Kirjoitus ideaalisen ehtona on nimenomaan tätä poispyyhkiytymistä. Se on kuitenkin, kuten Derrida myöhemmissä teksteissään kirjoittaa, "vaarallinen täydennys". Kun kirjoituksen näyttämö on avautunut, "kielen viettelystä” ei voi enää pitää kurissa. Siksi tieteen ja eurooppalaisen kulttuurin kriisi ei ole ymmärrettävissä missään sellaisessa mielessä, jossa siihen vastattaisiin joko nostalgialla tai välittömän menettämisestä juontuvan kielen turmeltuneisuuden puhdistamisella.

Vaikka Husserl siis avaakin ajattelussaan kielen konstitutiivisen viettelyksen vaaran, hän ei lakkaa vastustamasta sitä ja vaatimasta kielen puhtautta. Derridan mukaan fenomenologinen reduktio on nimittäin yritys puhdistaa kieli, "sulkeistaa empiirinen kieli tai köyhdyttää se menetelmällisesti yksiselitteisten ja käännettävien rakenneosien todelliseen läpinäkyvyyteen saakka”. (GA, 116.) Tämä Husserlin yritys ei voi onnistua, se ei voi olla lykkääntymättä loputtomasti, sillä äärellisten kokonaisuuksien olemukset ovat palautumattomalla tavalla empiiriseen tosiasiahistoriaan kuuluvia ideaalisuuksia. Kyse on erityisestä äärellisen olevan suhteellisuudesta, taloudesta, josta tulee tärkeä osa Derridan myöhempää ajattelua. Tätä taloutta Husserl ei Derridan mukaan koskaan käsitteellistä.

Koska Husserl lähtee mahdottomalla tavalla vastustamaan avaamansa ehtojen to- dellistumista, idealisoiva akti tulee Husserlilla kuvatuksi kaikkein konkreettisimmillaan "rajan lähestymisenä". (GA, 162.) Tällä on Derridan mukaan vakavia seurauksia. Kyse on nimittäin siitä, että näin ideaalisuutta ei ajatella, toisin kuin on tarkoitus, asiasta itsestään käsin, vaan kaikkea fenomenologista näkemistä määrittää tekijä, joka jo ennakolta turvaa kohteen pysyvyyden lähestymisen ja asettaa näin sen ideaalisuuden. Tämä tekijä on Derridan mukaan idea. Idealisaation ytimeen jää idea kantilaisessa mielessä äärettömän toiston ja lähestymisen alueena. Tätä ideaa reduktio ei koskaan paljasta.

Ideaalisuuden oleminen määrittyy näin äärettömän lähestymisen kautta. Ideaalinen kohde ilmenee siinä, että se sallii lähestyä itseään äärettömästi. Näin kysymättä jää kuitenkin tämän lähestymisen ehto, se mikä pitää tämän lähestymisen aktin koossa. Husserl ajattelee tätä tietoisuuden ykseyttä "elävän nykyisyyden" (lebendige Gegenwart) nimissä. Elävä nykyisyys on subjektin konstituution ydin, josta käsin tietoisuuden tulevat ja menneet intentionaaliset kohteet, protentio ja retentio pysyvät yhdessä. Derridan sanoin elävä nykyisyys on "tämän kaksoissisältymisen määrittelemätöntä ylläpitoa”. (GA, 164.) Sikäli kuin intentionaalisuus on liike tästä elävästä nykyisyydestä ulos kohteeseensa ja takaisin, ajattelematta uhkaa jäädä tämän liikkeen mahdollistava ykseys.

Ideasta tulee se, mikä on asetettu, jotta ideaalisen tunnistaminen ja lähestyminen tulisivat mahdollisiksi. Ideaalinen ei nimittäin voi ilmetä ja olla tunnistettavissa äärettömänä muuten kuin sitä kaut- ta, että sen ykseys edeltää sitä ideana. Derrida kirjoittaa, että tämä elävän nykyisyyden absoluutti "ei ilmene sellaisenaan [...] muuten kuin jos tämän liikkeen ykseys antaa itsensä määrittelemättömänä ja jos sen määrittelemättömyyden mieli ilmenee nykyisyydessä". (GA, 165.) Tämän ykseyden tulee kuitenkin aina jo olla läsnä. Derridan mukaan kyse on kantilaisesti ymmärretystä ideasta: konstituoivan subjektin perustaa oletus subjektiviteetin ykseydestä, elävä nykyisyys ideana, joka "ilmaisee itsensä ilmenemättä ja olematta nykyisyyden sisältönä" (mts.). Tässä mielessä idea on ennalta asetettu ja ajattelematta jäävä äärettömän kuva

Näin elävä nykyisyys on Derridan mukaan "fenomenologinen absoluutti". Se on puhdas ilmenemisen mahdollisuus ja fenomenologisen näkemisen aukeama, "näkemisen näkymätön ympäristö", joka ohjaa kaikkea fenomenologisen tarkastelun piiriin tulevaa ilmenemistä. (GA, 166.) Kun intentionaalisuus on tietoisuuden suuntautumista kohteeseensa, tämä fenomenologian absoluutti on intentionaalisuuden liikkeen ykseys, intentionaalisuus itse. Derridan sanoin se on "puhtaan intention napa", se mikä tuossa kohteessa on objektiivista tai "laajassa mielessä itse objektiivisuus" (GA, 168).

Fenomenologialle näin avautuva vaade ei kuitenkaan ole vain ikään kuin vaade mennä vielä pidemmälle tai paljastaa yhä syvempiä rakenteita. Kyseessä on itse asiassa hegeliläinen kysymys ajattelun "oikeasta" aloittamisen tavasta. Kyse on suhteesta alkuperään, jota Husserl ja koko fenomenologian projekti juuri vaalii. 
Derridan mukaan Husserlin ajattelun vaara on ilmaistavissa siten, että tämän fenomenologisen selvittämisen työn logos uhkaa olla subjektin tuolla puolen. Tällöin tuon logoksen transsendenssi ei enää olisi transsendenssi vaan vain pelkästään subjektiviteetin täyttymisen napa. Logoksella nimittäin on aina teloksen muoto. Kuten edellä todettiin, jokainen selvittäminen on aina suhteessa selvittämisensä päätepisteeseen, jota se ei voi ottaa haltuun ja joka asettuu vain suhteessa selvittämiseen. Husserlin vaarana onkin tämän ikään kuin ensimmäisen menetyksen lunastaminen takaisin toisella tasolla. Ajattelemalla selvittämisen päätepistettä jonakin, jonka selvittävä subjektiviteetti on kyllä menettänyt, mutta jonka ankaran tieteen absoluuttinen logos tästä huolimatta voi tavoittaa, Husserl tulee ajatelleeksi kielen transsendenssia subjektiviteetin täyttymisenä, ei enää transsendenssina sellaisenaan. Tällä tavalla järki saa aseman hengen itse-selvennyksen itsenä, selvittävän subjektiviteetin ylemmän tason ykseytenä.

Sikäli kuin fenomenologia pitää kiinni subjektin ja kielen erosta, se pitää kiinni absoluuttisesta logoksesta, järjestä tuon subjektiviteetin täyttymisen pisteenä. Siksi historia on Husserlille ideaalisen historiaa - ei kylläkään mitään naivia edistysuskoa, mutta lopulta kuitenkin historian mielestä kiinni pitämistä järkenä. Näin Derridan muistutus koskeekin Husserlin ajattelun taipumusta, jossa tämä uhkaa menettää logoksen transsendenssin sellaisenaan, ylimäärän joka on kysymisen mahdollisuuden ehto. Jotta tämä mahdollisuus pysyisi auki, filosofisen selvittämisen keskus pitäisi pitää avoimena, tapahtumallisena transsendenssina. Derridan sanoin se olisi tällöin pelkkä "artikulaation paikka eli logoksen välittymistä niin että se saa itsensä tässä välittymisessä" (GA, 177).

\section{TRANSSENDENTIN UUSI MERKITYS JA MARXISMIN HENKI}

Viime vuosisadan alkupuolella fenomenologiaa pidettiin marxilaisen ajattelun piirissä lähes poikkeuksetta "eksistentialismin" eräänä muotona. Jean-François Lyotard kirjoittaa pienessä La phénoménologie -kirjasessaan (1954) Husserlin fenomenologian olevan kaikista ansioistaan huolimatta eräänlainen filosofian laimea "kolmas tie", joka vain täyttää "ideologisen tehtävänsä". Tällaiset huomiot ovat nykylukijalle totta kai osaltaan vitsikkäitä, mutta se, mitä kautta näihin tuomioihin aikoinaan päädyttiin, tuo esiin yhä merkitseviä piirteitä Husserlin fenomenologiasta.

Derrida ei koskaan myöntänyt lähteneensä mukaan opiskeluaikansa yliopistomarxilaisuuteen. Geometrian alkuperän johdannon huomautuksissa hän kuitenkin useaan kertaan viittaa kunnioituksella 40-50-luvuilla Pariisin yliopistopiireissä vaikuttaneen Tran-Duc-Thaon teokseen Phénoménologie et matérialisme dialectique(1951). Tämän teoksen pyrkimyksenä on näyttää, kuinka Husserlin fenomenologia ainutlaatuisella tavalla avaa filosofian kysymyksen oikein, mutta ajautuu umpikujaan, ja kuinka dialektinen materialismi näyttää kysymisen uuden suunnan yhtä aikaa hyväksymällä ja ylittämällä fenomenologian. Fe- nomenologian sietämätön ristiriita on siinä, että vaikka merkityksellistä maailmaa ajatellaankin lähtien annettuudesta ja elämismaailmasta, subjektiviteetin passiivisten synteesien tasosta, subjektin kokonaisuudesta ei kuitenkaan luovuta koskaan. Tämän sijaan alkuperäinen konstituoiva subjektiviteetti tulisi ymmärtää materiaalisena, materiaalisen dialektisenä liikkeenä.

Tässä kohtaa Derridan Husserl-luennan suunnan voi nähdä samana. Marxilaisin termein syytös koskee Husserlin ajattelun ideologisuutta. Husserl uhkaa siis ajautua ajattelemaan, että logoksen transsendenssilla on teleologinen täyttymisen napansa, logoksen tapahtumiseen nähden ylemmän tason ykseys transsendenttina subjektiviteettina. Tämä järjen ajattelematta jättäminen on ideoiden ja tätä kautta niiden merkityksellisen maailmamme pysyvyyttä säätelevän vallan ajattelematta jättämistä, ideologisuutta.

Derridan väite on, että tähän ideologian vastustamiseen kytkeytyy koko ajattelun mahdollisuus kysymisenä. Kyse ei siis ole mistään aatteellisesta marxilaisuudesta sinänsä vaan, kuten Derrida itse myöhemmin esimerkiksi Spectres de Marx -teoksessaan on kirjoittanut, tietystä "marxismin hengestä". Tämä henki merkitsee Derridan mukaan tiettyä "radikalisaation" elettä suhteessa perinteeseen, kysymisen mahdollisuuden auki pitämistä. Tässä tapauksessa on kyse husserlilaisen jälkikysymyksen mahdollisuuden vaalimisesta vastustamalla tämän avaamisen tuottamaa vaaraa.

Jos kerran ontologia on jotakin muuta kuin pelkkää 
empirististä tosiasioiden toteamista, sen kysymys "miksi" on mahdollinen vain tosiasiallisuuden ei-olemisen mahdollisuudesta käsin. Tämä eiolemisen mahdollisuus avautuu edellä kuvatulla tavalla fenomenologisessa, Derridan mukaan "vain fenomenologisessa", kysymyksenasettelun jälkikätisyydessä, kun olevan olemusta kysytään lähtien sen mahdottomasta alkuperäisestä annettuudesta. Vain tästä käsin ontologisella kysymyksellä ja vastauksella on painoa. Derrida kirjoittaa, että vain koska fenomenologisesti tarkasteltuna mieli, siis $l^{-}$ goksen kokonaisuus, selventämisen suunta, ei ole mikään oleva ja voi "aina olla ruumiillistumatta, kuolla ja olla syntymättä", ontologian kysymys miksi "saa elinvoimansa kysymyksenä mitä varten". (GA, 183). (Tässä suomennos kuuluu hyvin kummallisesti: "Näin siksi, että merkitys, johon meillä on pääsy, ei ole tapahtuma-olio, se ei voi koskaan olla ruumiillistumatta, sammua tai olla syntymättä, kun miksi säilyttää fenomenologisen varmuuden arvonsa ja sen kautta ainoastaan löytää mistä näkyvillä olevan elinvoiman”. Tämä ei harmillista kyllä ole suinkaan ainoa lause, jonka kääntämi- nen on jäänyt kesken.)

Ontologia tarvitsee siis aina sekä fenomenologisen avauksen että vahvistuksen. Tässä kysymisen tilaa määrittää kaksoisside. Ontologinen kysymys voi siis avautua vain fenomenologiassa. Ilmenemisen kannalta tämä kysymys suuntautuu kohti sitä, mikä ilmenee ilmenemättä. Kysyessään alkuperää fenomenologia suuntautuu siis kohti mahdotonta ilmiötä, sitä mikä ei enää kuulu fenomenologian piiriin.

Tässä mielessä Husserlin ajattelun vaara on juuri siinä, että hän ei suostu päästämään irti historian mielestä, selventävän logoksen täyttymisen pisteestä järkenä. Tämä nimittäin olisi ajattelun fenomenologisesta lähtökohdasta avautuva, ikään kuin epä-fenomenologinen vaade. Ajattelun on käännyttävä kohti mielen loppua, tai hegeliläisittäin, hengen on saatava näkymä hirvittävään negatiiviseen luonteeseensa. Näin myöskään kuolema ei missään nimessä ole Heideggerille vain mikä tahansa fenomenologisen tarkastelun kohde.

Derrida vaatii siis kiinnittämään huomiota jälkikysymyksen avaamaan mahdollisuuteen. Fenomenologisen kysymyksen avaamaa ontologisen kysymisen mahdollisuut- ta ei koskaan voi palauttaa fenomenologiseen selvitykseen välittömästi. Ontologisen ulottuvuuden aukeama sulkeutuu nimittäin konstitutiivisesti heti tai ennen kuin fenomenologinen kuvaus alkaa. Tämä selventäminen on ikään kuin aina jo myöhässä. Ontologialla itsellään taas on oikeus vain kysymykseen.

Se mikä sitoo tämän kiistan yhteen, on siis kyllä historiallisuus, mieli historiallisuutena, mutta tämä ei kuitenkaan ole mitään muuta kuin pelkkä logoksen ja selventämisen tapahtumisen paikka, "yhteenkietoutumisen ja kerrostumisen elävää liikettä". Transendentaalista olisi vain tämä logoksen tapahtuminen viivenä, tai Derridan termein, palautumattomana erona. Siksi selventävällä subjektiviteetilla, "meillä" logoksen tapahtumana, ei ole mitään mahdollisuutta löytää tämän selventämisen kokoavaa ykseyttä, oli sitten kyse järjestä (jolloin voisimme määritellä itsemme järjellisiksi ja tätä kautta humanismin hengessä ihmisiksi kuten Husserl on taipuvainen tekemään), jumalasta tai kansasta. Tässä on Derridan mukaan fenomenologian voima, jota on vaalittava pitämällä se voimana, vastustamalla sitä. 